\title{
Investigating the Impact of Airport Relocation on the Transport Network in Special Region of Yogyakarta, Indonesia
}

\author{
Andrean Gita Fitrada*, Ahmad Munawar, Dewanti \\ Department of Civil and Environmental Engineering, Universitas Gadjah Mada, INDONESIA \\ "Corresponding author: andreanfitrada@gmail.com
}

SUBMITTED 20 March 2019 REVISED 11 April 2019 ACCEPTED 23 April 2019

\begin{abstract}
Adi Sutjipto International Airport is the airport currently operated in Special Region of Yogyakarta (SRY), located near the city centre area. SRY needs to construct a new airport due to the increase in air passengers. The proposed airport, named New Yogyakarta International Airport (NYIA) is located in the undeveloped area, away from the city centre. This study is aimed to investigate the impact of airport relocation to the road network and to assess several developments of transportation infrastructures to the new airport. The analysis was conducted by developing a transport network model using PTV Visum. The secondary data collected from the local government to develop the transport network model, including the development of origindestination matrices and forecasting purpose. The scenarios of road infrastructures development and new rail service to the airport in 2025 are then modelled. The results showed that the road infrastructure developed can reduce the number of congested main roads from $9.47 \%$ into $5.94 \%$. Rail service to the airport is effective to decrease the traffic congestion at two NYIA roads access and able to increase their average speed from 49.45 and $44.29 \mathrm{~km} / \mathrm{h}$ into 66.45 and $62.66 \mathrm{~km} / \mathrm{h}$.
\end{abstract}

KEYWORDS Macro simulation; Airport relocation; Airport train; Outer ring road

(C) The Author(s) 2018. This article is distributed under a Creative Commons Attribution-ShareAlike 4.0 International license.

\section{INTRODUCTION}

Adi Sutjipto International Airport is an airport operated in Special Region of Yogyakarta (SRY), located in Depok, 7 kilometres away from the city centre of Yogyakarta. The passenger terminal in Adi Sutjipto Airport, Yogyakarta was designed to accommodate a maximum number of 1.5 million passengers/year. However, the number of passengers served in Adi Sutjipto Airport reached 6.4 million passengers/year at the end of 2015 (Angkasa Pura, 2015). The development of the existing airport is no longer possible because of the limited area and the existence of natural obstacles around the area, such as Gumuk Ijo hills and Kuning River.

According to the report from Angkasa Pura (2015), the number of aircraft movement, passengers, and cargo in SRY will increase around $8.24 \%, 11.72 \%$, and $10.13 \%$ per year, respectively. The report also predicted that in 2030, the number of aircraft movement would reach 102,000 movements/year, the number of passengers in Yogyakarta will reach 10.37 million passengers/year, while the number of cargo movement will reach 30,400 ton/year.

Therefore, SRY needs to construct a new airport in a different location with a wider area by considering the capacity of the apron, a number of passengers, and the air traffic growth in the future. The proposed airport, named New Yogyakarta International Airport (NYIA) located in Temon, Kulon Progo, which is 40 kilometers away from the city centre area. The airport is proposed to operate by the end of 2019. In the first phase proposal, the airport is designed to serve 10 million passengers/year, and will have a $3250 \mathrm{~m}^{2}$ runway and $106500 \mathrm{~m}^{2}$ terminal for passengers (Ministry of Transport, 2013).

The new airport will create a new travel demand with the increase in trip generation and attraction in the area, which located away from the city centre. To support the development of NYIA and its surrounding, several developments for transportation facilities such as roads and railway is proposed. The airport will have two primary access through Yogyakarta-Purworejo Road and Jalur Lintas Selatan Road (JJLS). Additional, Jogja Outer Ring Road (JORR) would support these two main accesses.

\section{LITERATURE REVIEW}

\subsection{The Effects on Airport Relocation and Expansion}

First, earlier studies reviewed in this chapter are about the effects on airport relocation. Studies by Loo and Chow (2011) and Lindarto (2017) explained about airport relocation from the city centre area into the 
new undeveloped area away from the city centre. These study cases are similar to this study, which will assess the impact on airport relocation from Adi Sutjipto International Airport in the city centre area to new undeveloped area in Temon district. Both studies indicated that airport relocation would increase the generation and attraction of the new airport location. Moreover, Loo and Chow (2011) and Purwanto et al. (2017) suggested that airport relocation to the new area should be supported with several improvements to facilitate the people moving from and toward the airport, in these cases are highway and rail service.

\subsection{Development of Road Infrastructures}

In the next studies, Rahayu, Ahyudanari and Pratomoadmojo (2016) found that the development of land use around the airport can increase travel time on road access to the airport if there is no road improvement. While Smith (1978) stated that the development of alternative roads such as bypass and ring road could be a good measure to reduce traffic congestion in the city centre area. These cases correspond to the plan on the SRY network, which planned to develop JORR and other road improvements to reduce the traffic congestion in the city centre area.

\subsection{Railway Service as Ground Access to the Airport}

The next studies reviewed are about the rail service as the ground access to the airport. Ashley and Merz (2006) identified several key elements of successful airport trains. The most noticeable key aspect is the long distance from the airport to the city centre area. This case is similar to two other studies and this study. A study by Jou, Hensher and Hsu (2011) in Taoyuan International Airport, Adi and Tamtomo (2015) in Soekarno-Hatta International Airport, and this study in New Yogyakarta International Airport are all planned to be connected to the rail service and located away from the city centre. A study by Jou, Hensher and Hsu (2011) and Adi and Tamtomo (2015) also have a similar result which stated the journey time of airport train have a major role on the market share, while the airport train fare is considered less important.

\section{RESEARCH METHODS}

The method used in this research is divided into three different parts. The first part is the secondary data collection. The second part is the transport network development using PTV Visum software. The last part of the method is the projection of the future network condition in SRY. Overall, the method of this study is presented in the Figure 1.

\subsection{Study Area and Secondary Data Collection}

Special Region of Yogyakarta (SRY) is a province located in the middle of Java Island, Indonesia. With the population of 3.7 million inhabitants and area of $3133.15 \mathrm{~km}^{2}$ (Yogyakarta Bureau of Statistics, 2016), the SRY is the second smallest province in Indonesia, after the capital of Republic of Indonesia, Jakarta. This province into 78 districts, 12 districts in Kulon Progo, 17 districts in Sleman, 18 districts in Bantul, 18 districts in Gunung Kidul, and 14 districts in Yogyakarta. The zones division in this study will be based on the area of the district in SRY.

Data was collected from several institution and used for the development of traffic network model in SRY. Table 1 presents type and the source of data which was collected during this study. In general, all the data used in this study are secondary data. The traffic network model includes the development of origindestination matrices, the road network in the study area, and the data for validation of the network. 


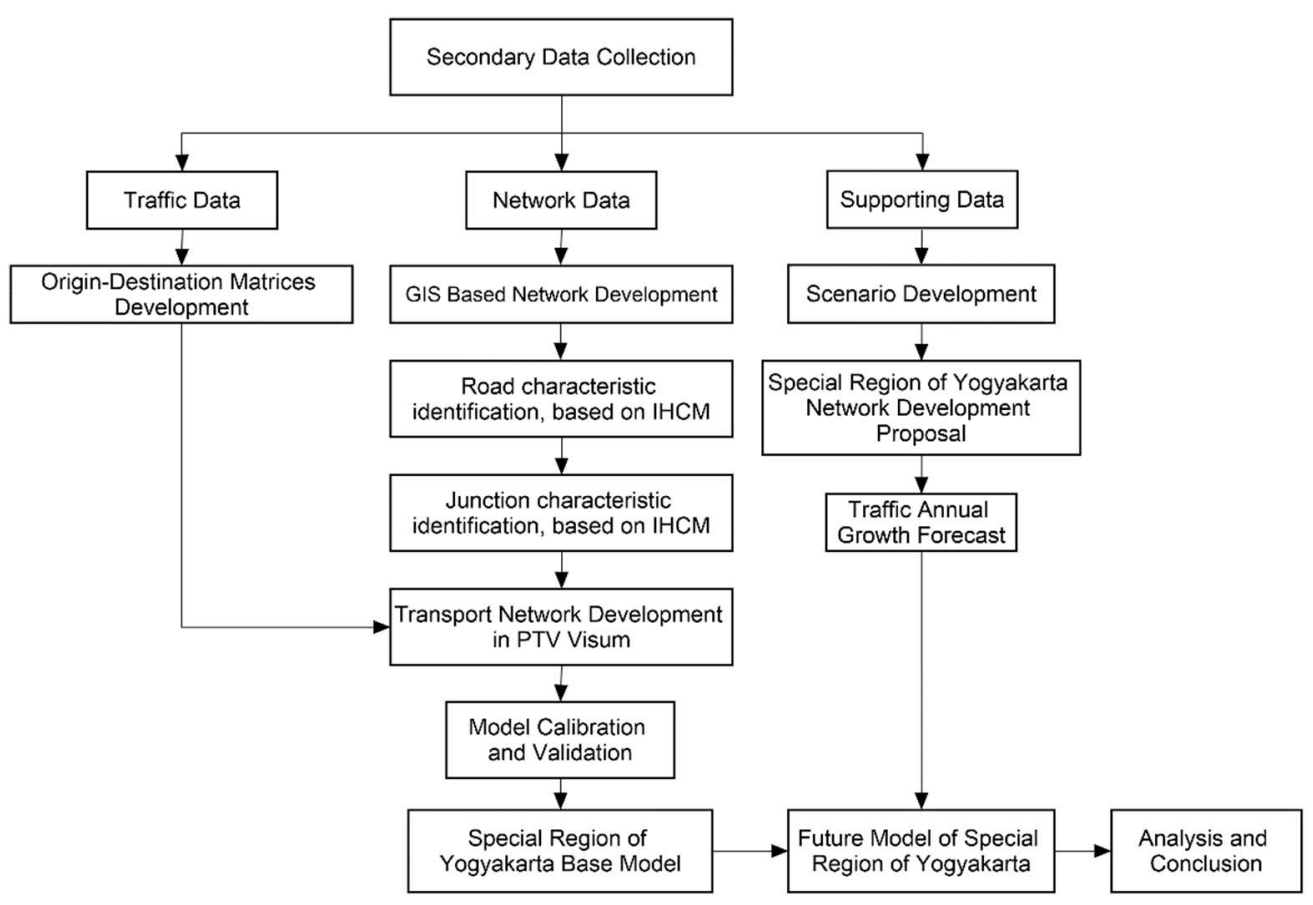

Table 1. Secondary data

Figure 1. Flow Chart of Research

\begin{tabular}{|c|c|c|}
\hline Data & Purpose of data & Source \\
\hline Origin-destination matrices & As an input in PTV Visum & \multirow{3}{*}{$\begin{array}{l}\text { Department of } \\
\text { Transportation, SRY }\end{array}$} \\
\hline Traffic counting data & Traffic Flow Validation in PTV Visum & \\
\hline $\begin{array}{l}\text { New Yogyakarta Int. Airport } \\
\text { masterplan }\end{array}$ & Specify the location of the new airport & \\
\hline Road network map & Develop the road network in PTV Visum & \multirow{3}{*}{$\begin{array}{l}\text { Department of Regional } \\
\text { Development, SRY }\end{array}$} \\
\hline Existing and future land use map & $\begin{array}{l}\text { Identify the potential of new generation and } \\
\text { attraction in the future }\end{array}$ & \\
\hline $\begin{array}{l}\text { Road Infrastructures future } \\
\text { development maps }\end{array}$ & Develop the future road network in PTV Visum & \\
\hline Roads specification & $\begin{array}{l}\text { Identify the road characteristic as input in PTV } \\
\text { Visum }\end{array}$ & \multirow{2}{*}{$\begin{array}{l}\text { Department of Public } \\
\text { Works, SRY }\end{array}$} \\
\hline $\begin{array}{l}\text { Road Infrastructures design } \\
\text { proposal }\end{array}$ & $\begin{array}{l}\text { Identify the future road characteristic as input } \\
\text { in PTV Visum }\end{array}$ & \\
\hline Air Traffic Data & Forecast the air traffic growth & PT. Angkasa Pura I \\
\hline
\end{tabular}

\subsection{Network Development}

The process of network development in this study begins with the operation of GIS-based programs. The GIS-based programs are used to plot the roads and determine the zones to develop a transport network model in PTV Visum. The GIS-based programs that mainly used in this step are Google Earth Pro, Global Mapper, and Quantum GIS (QGIS).

After the road network and zones map imported to the PTV Visum, several steps need to be completed before the model is ready to be used. The links and junctions characteristics should be identified, such as capacity, link directions, free flow speed, number of lanes, blocked vehicles, delay, type of junctions, signal time, and turning movements in every junctions. The identification of links and junction characteristics is based on the Indonesia Highway Agency (1997).

The input of origin and destination matrices is needed to develop a road network model in SRY completely. The origin and destination data that will be used in this study is data from the SRY local government in 2015. The data consist of the total number of generation, attraction, and the origin-destination (OD) pair trip per day in every zones, which are 78 internal zones and four external zones. The data input in PTV Visum that 
will be used in the model is the origin-destination (OD) pair trip in a peak hour period. However, adjustment to convert the traffic data from daily traffic into peak hour traffic is needed. According to AASHTO (2011) in rural arterials road, the portion of traffic volumes in peak hour will be about $12 \%$ of the average daily traffic volumes (ADT). Hence, in this study the peak hour factor around $12 \%$ will be used in trial and error method to convert the number of daily trips into peak hour period, until the model represents the real condition.

Lastly, a study by Irawan, Sumi and Munawar (2010) about the application of BPR VDF and IHCM VDF to model road transport network in Indonesia showed that IHCM VDF produced a better result for the traffic assignment in the Indonesian road network. However, both VDF are common to be used in the Indonesian road network. In this study, the VDF to be used in the model is the BPR VDF, because the PTV Visum software used in this study used BPR VDF as the default function to iterate the traffic volume in the assignment.

\subsection{Scenario Models Development}

In this study, the scenario models developed to predict the traffic condition at the SRY in 2025. The main

\subsubsection{Scenario 1: Road Infrastructure Development in Special Region of Yogyakarta}

The first scenario to be implemented is the road infrastructure development in the study area. The model developed from the existing network with the addition of several government proposals of road development in the SRY. The proposals are including JORR, JJLS, the airport road access alternative 1 (JogjaPurworejo Road) and alternative 2 (through JJLS). The newly developed road characteristic will follow the government proposal based on the report from the Department of Public Works (2017), and then the speed and capacity will be calculated based on Indonesia Highway Agency (1997). The analysis will assess the traffic condition in 2025, and the effectiveness of road development to accommodate the traffic in the future.

\subsubsection{Scenario 2: Introduction of New Rail Service to the Airport}

The second scenario is developed by implementing scenario 1 with the addition of new rail service to the airport as can be seen in Figure 2. The trace of a new modification in this step will be the change in origin and destination matrices as the impact of airport relocation. The other scenarios that will be developed are the implementations of the several proposals of infrastructures development at the SRY.

The relocation of the airport in SRY from Adi Sutjipto International Airport, in Depok district to NYIA, in Temon district will have an impact in the change of the origin and destination matrices data in the study area. In this step, the generation and attraction of the Adi Sutjipto International Airport in Depok district will be shifted to the location of NYIA, which is located in Temon district. The annual road traffic growth to predict the traffic in the future calculated using regression method based on the Directorate General Bina Marga (2017), while the air traffic growth that will be used in this study is based on the annual report from Angkasa Pura (2015).

The new matrices in SRY need to be balanced to reach the convergence. The method of matrices balancing in this study used the bi-proportional method. The process will be stopped after the convergence reached, which shown by the small value of correction factors within a reasonable tolerance. In this study, the tolerance factor set to be $1 \%$. After all of the steps above conducted, the 2025 origin and destination matrices are ready to be used.

rail network to the airport is following the study by Suwarsono and Hidayat (2013) about the development of airport rail service to connect the NYIA. The result showed that the rail trace connecting Yogyakarta, Wates, Kedundang, and NYIA is the best trace compared to the other alternatives. In the other study, Suryadwanti (2016) stated that Yogyakarta Rail Station located in Gedongtengen is the most suitable rail station to have the airport train service. Another study, Fitriatmaja and Irfan (2015) studied about the passengers' preference of the airport train service proposed in the new relocated airport in SRY. The result showed that for the airport train service, the most important aspect is speed, punctuality, and facilities, while the fare is less important. This could be showed by the result of the study which stated that the scenario selected for the airport train in SRY had the highest ticket fare and had the most decent facilities including carriage facility, internet access, and high speed. These results correspond to the report from Kereta Api Indonesia (2015) as the train and rail operator in Indonesia. 
To predict the rail service mode share, the utility of all modes to access the airport should be identified. According to Adi and Tamtomo (2015), the variables that will affect the passengers choice in the rail service to the airport will be cost, in-vehicle time, and waiting time. Hence, the formula of the utility of each mode can be calculated using the Equation 4 .

$U_{i}=\delta_{1}+\beta_{\text {Time }} \times I V T_{i}+\beta_{\text {cost }} \times$ Cost $_{i} \times \beta_{\text {WaitTime }} \times$ WaitTime $_{\mathrm{i}}$

where $U_{i}$ is utility of mode $i ; \delta$ is alternative specific constraint and $\beta$ is coefficients of each variable

The study by Adi (2015) using Nested Logit (NL) method in case of Soekarno-Hatta International Airport showed that in a model with no alternative specific constraint the value of each coefficient $(\beta)$ are as shown in Table 2 .

Table 2. Variable coefficients for the utility function (Adi and Tamtomo, 2015)

\begin{tabular}{ll}
\hline Variable & Coefficient $(\beta)$ \\
\hline Cost & $-2.1 \mathrm{E}-05$ \\
Waiting Time & -0.03 \\
In-Vehicle Time $(I V T)$ & -0.021 \\
\hline
\end{tabular}

Adi and Tamtomo (2015) indicated the values of InVehicle Time and Waiting Time in $(\mathrm{Rp} / \mathrm{min})$ are 1019.05 and 1428.57 respectively. The study by Adi and Tamtomo (2015) is considered fit to the condition in the case of rail service proposal to NYIA. The similarity between the studies is both of the studies located in Indonesia, which assumed that the people would have the same culture and preferences. Furthermore, both studies are predicted the similar case about the introduction of new rail service mode share towards the airport located away from the city centre.

The zones that assumed will be affected by the introduction of rail service to NYIA only limited to the area near to the rail stations. The purpose of the trips using this rail service assumed only to reach NYIA and vice versa because the airport train fare will be considered too expensive for home-based work commuting trip. The travel time, waiting time, and train fare are modelled according to the government proposal of the rail service to NYIA based on the report from Kereta Api Indonesia (2015), while for private vehicles, the travel cost and travel time are estimated using the result on scenario 1 .

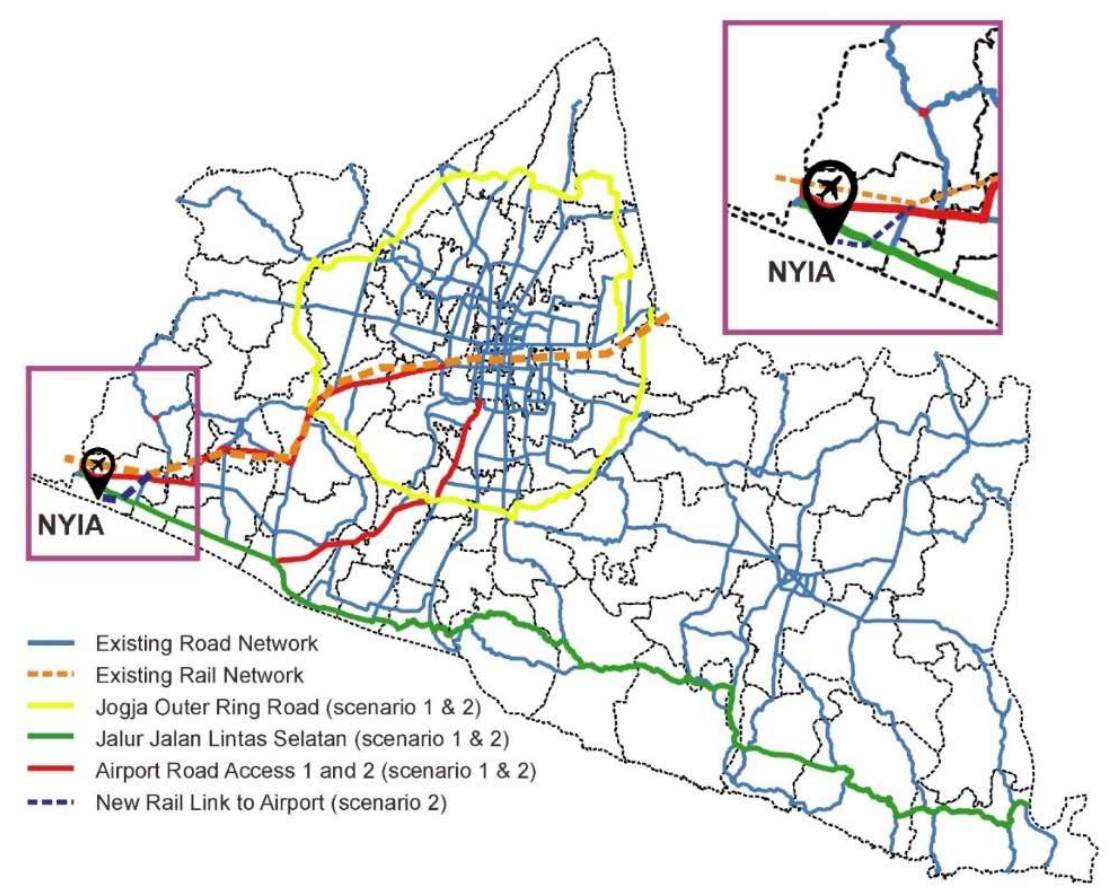

Figure 2. Scenario models

The probability of the passengers choosing rail service to the airport is then calculated for an origin- destination pair in the zones included. The formula to calculate the probability can be seen in the Equation 5 . 
$\mathrm{P}_{\mathrm{i}}=\frac{\mathrm{e}^{U_{i}}}{\sum \mathrm{j}^{U_{j}}}$

where $P_{\mathrm{i}}$ is probability choosing mode $i ; U_{\mathrm{i}}$ is utility of mode $i$

After the proportion of the rail service user calculated, the origin-destination matrices should be modified to model the movement to the stations. The destination zone that used to be the airport location shifted to the location of the nearest rail station, followed by matrices balancing step using a bi-proportional method using Equation 12. The analysis will assess the traffic condition in 2025 especially the road access to the NYIA, after the introduction of the new rail service to the airport.

\section{ANALYSIS AND RESULTS}

\subsection{Model Validation}

In this study, the network model of the SRY is tested by comparing its output in terms of modelled flow and average speed in several links. The data used in the validation process consists of flow and average speed data at 25 different links, located in different regencies. The data showed in the analysis below is the best condition, which is obtained from the final trial and error in the model development step.

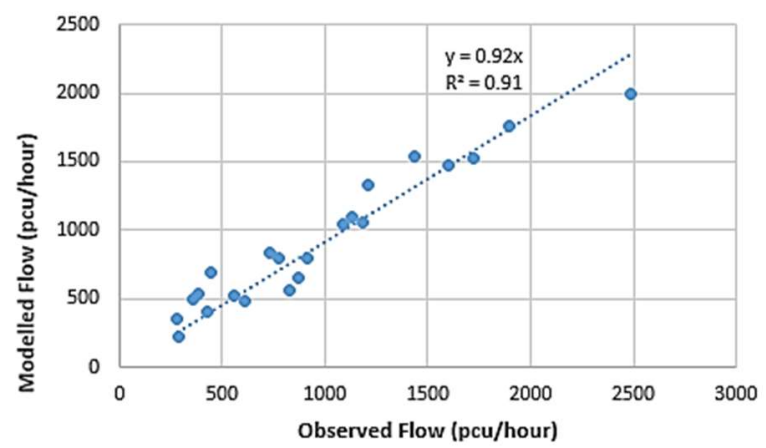

Figure 3. Linear regression between observed flow vs modelled flow

The list of GEH values in 25 different tested links can be seen in the Table 4.
According to Ortuzar and Willumsen (2011), to assess the goodness of calibration process, it can be started by plotting the observed data against the model output and create a linear regression, which intercepted to zero. Ortuzar and Willumsen (2011) stated that the closer the value of slope (y) and intercept $\left(\mathrm{R}^{2}\right)$ to 1 the better the model will be. In this case, Figure 3 and Figure 4 show that the $\mathrm{y}$ value and $\mathrm{R}^{2}$ for both traffic flows and average speeds data are close to 1 , which are 0.92 and 1.11 respectively. The $\mathrm{R}^{2}$ value for both traffic flows and average speeds also showed a good result, which both of them have the value close to 1 , which are 0.91 and 0.90 respectively.

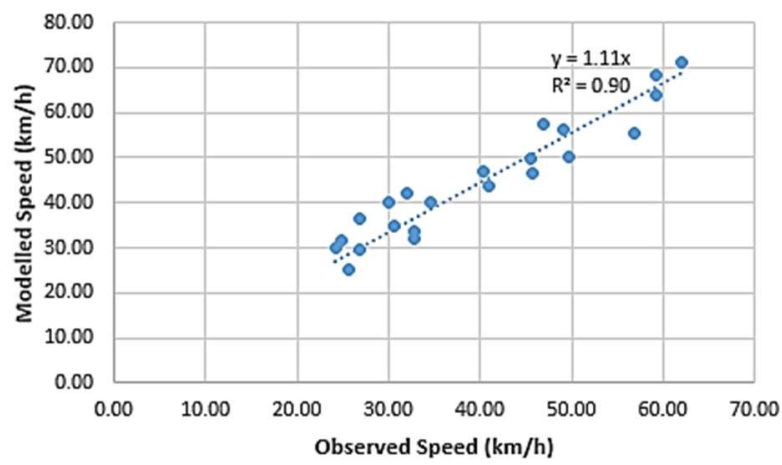

Figure 4. Linear regression between observed speed vs modelled speed

Another method that used to do the model validation in this study is using GEH measure. The formula to calculate GEH can be seen in the previous chapter. The validation process conducted by comparing traffic flow between observed and modelled flow based on the value of GEH. The criteria of GEH value is presented in Table 3.

Table 3. The implications of GEH value (UK Highways Agency, 1996)

\begin{tabular}{ll}
\hline GEH Value & Comment \\
\hline 1 & Excellent \\
2 & Good \\
5 & Acceptable \\
10 & Poor \\
\hline
\end{tabular}


Table 4. Results on GEH validation process on traffic flow (pcu)

\begin{tabular}{|c|c|c|c|c|c|c|c|c|c|}
\hline Road Link & Observed & Modeled & Differences & GEH & Road Link & Observed & Modelled & Differences & GEH \\
\hline Solo Rd 1 & 1088 & 1038 & -50.1 & 2 & $\begin{array}{l}\text { Kaliurang } \\
\text { Rd } 3\end{array}$ & 386 & 541 & 154.8 & 7 \\
\hline Solo Rd 2 & 2490 & 1994 & -496 & 10 & Monjali St & 442 & 686 & 244.2 & 10 \\
\hline Adi Sutjipto Rd & 1895 & 1758 & -137 & 3 & $\begin{array}{l}\text { AM Sangaji } \\
\text { St } 1\end{array}$ & 555 & 525 & -29.6 & 1 \\
\hline Magelang Rd 1 & 1723 & 1521 & -202 & 5 & $\begin{array}{l}\text { AM Sangaji } \\
\text { St } 2\end{array}$ & 291 & 216 & -75.3 & 5 \\
\hline Magelang Rd 2 & 1433 & 1535 & 101.6 & 3 & Godean Rd 1 & 824 & 559 & -265 & 10 \\
\hline Magelang Rd 3 & 1182 & 1051 & -131 & 4 & Godean Rd 2 & 771 & 801 & 30.11 & 1 \\
\hline Wonosari Rd 1 & 872 & 648 & -224 & 8 & Bantul Rd 1 & 431 & 403 & -28.3 & 1 \\
\hline Wonosari Rd 2 & 1205 & 1332 & 127.4 & 4 & Bantul Rd 2 & 916 & 794 & -122 & 4 \\
\hline Wonosari Rd 3 & 733 & 838 & 104.6 & 4 & $\begin{array}{l}\text { West } \\
\text { Imogiri Rd } 1\end{array}$ & 611 & 484 & -127 & 5 \\
\hline Kaliurang Rd 1 & 1596 & 1478 & -118 & 3 & $\begin{array}{l}\text { West } \\
\text { Imogiri Rd } 2\end{array}$ & 283 & 353 & 70.14 & 4 \\
\hline Kaliurang Rd 2 & 1127 & 1097 & -30.1 & 1 & $\begin{array}{l}\text { Piyungan } \\
\text { Rd }\end{array}$ & 361 & 493 & 131.8 & 6 \\
\hline
\end{tabular}

According to traffic flow comparison in PTV Visum model and observed data, $73 \%$ of the links tested have GEH value not more than 5.0. Based on the validation process conducted above, it can be concluded that the SRY network model developed in this study is already good enough to reflect the real condition and can produce a good output for prediction purpose.

\subsection{Projection to 2025 Traffic Condition}

This study focused on predicting the new generation and attraction from the new relocated airport in the future. The NYIA is proposed to operate in 2019. The new airport will be located in Temon district and will replace Adi Sutjipto International Airport, which located Depok district. In this study, the traffic condition in 2025 will be forecasted, six years after the NYIA operated.

The trips from and toward Adi Sutjipto Airport is then projected using air passengers growth factor in SRY,
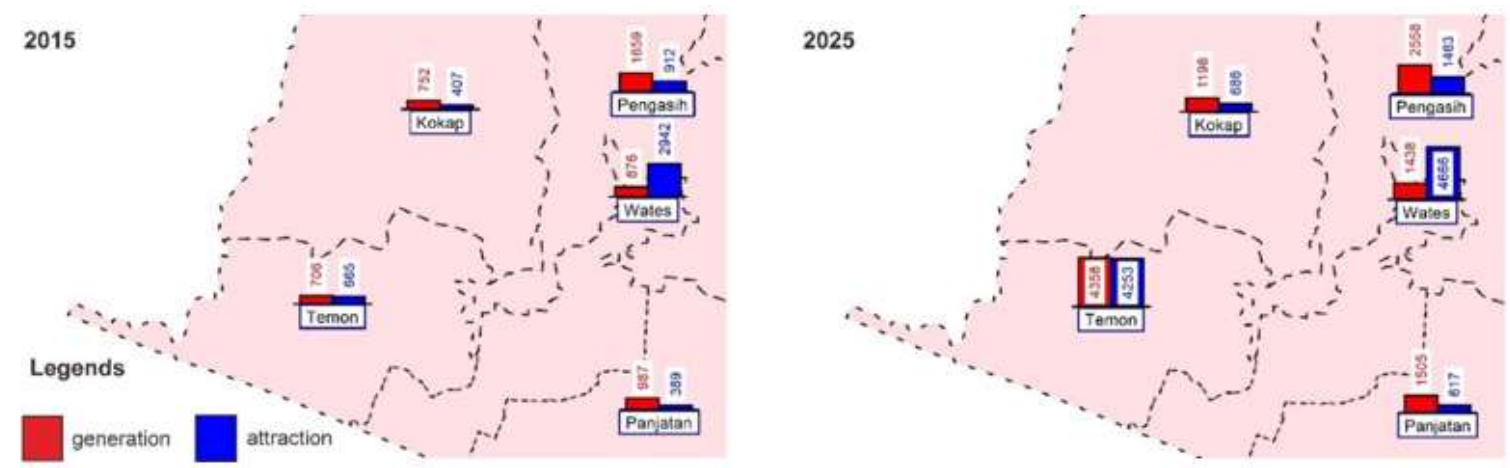

Figure 5. Change in generation and attraction in Temon district

which is $11.72 \%$ per year (Angkasa Pura, 2015). Meanwhile, the other road trips data are projected using road traffic growth factor of $4.8 \%$, which is based on the Directorate General Bina Marga (2017). The trips data generated and attracted from the existing airport that already projected to the year 2025 is then shifted to the new location in Temon district. The matrices are then balanced using bi-proportional method until convergence reached.

The change in total trips generation and attraction in Temon district in 2015 and 2025 can be seen in Figure 5 . As we can see from the figure below, the number of generation and attraction in Temon district significantly increased after the relocation of the airport from Depok district to the new location in Temon district. In 10 years, the generation and attraction in Temon district are increased more than six times, compared to only about 1.5 times increase in the other neighbour districts. 


\subsection{The result on Scenario Models}

The main purpose of this study is to forecast the future traffic condition as the impact of airport relocation and to assess the infrastructure development proposals in the SRY. There are three scenarios modelled in this study, which are do-nothing scenario, road infrastructures development in SRY scenario, and the introduction of new rail service to the NYIA scenario. All of the scenarios modelled in this study are the projection of traffic condition in 2025 .

From Figure 6, the increase in total travel distance exhibits a route diversion because of the existence of new roads as the new alternative routes. With the development of JORR, long distance trips will have alternatives to avoid congestions in the city centre area. Although the distance might be longer, the graph below showed an improvement in total travel time in the whole network. It can be presumed that road improvement is effective to provide alternative routes that can diverse the traffics and avoid congestions on several roads.
The graphs in Figure 6 also showed a slight reduction in both total travel distance and total travel time in scenario two if compared to result in scenario 1 . It is possible to happen because of the change in trips origin and destination which previously is the NYIA into the nearest railway station for several trips in the scenario 2 model.

Another result, it can be seen from the Figure 7 that the development of road infrastructures able to decrease the average volume over capacity ratio (VCR) and the number of the congested road in the SRY road network. The development of road networks modelled in scenario one able to reduce the average VCR about 0.08 , from 0.50 in do-nothing scenario into 0.42 . While the number of congested roads in scenario 1 , also decreased compared to do-nothing scenario. In scenario 1 , the number of congested roads, which have VCR more than 1.0 decreased to 45 links or $5.94 \%$ of the total links, compared to $9.47 \%$ in do-nothing scenario. The graphs also showed that scenario 2 has no significant effect on the VCR of the whole SRY network, and have the same number of congested road as the scenario before.

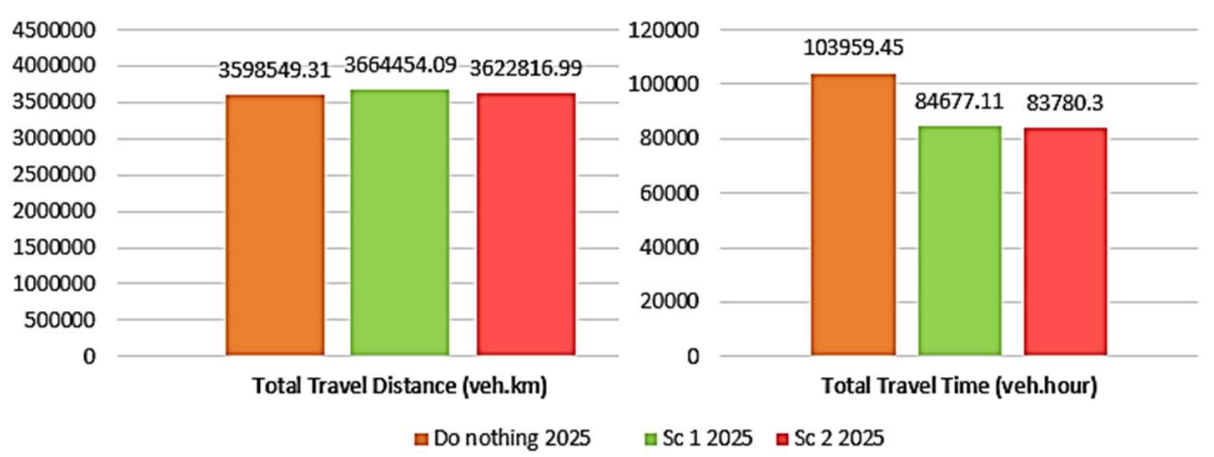

Figure 6. Comparisons on total travel distance (veh.km) and total travel time (veh.hour) between do-nothing 2025, scenario 1 2025, and scenario 22025
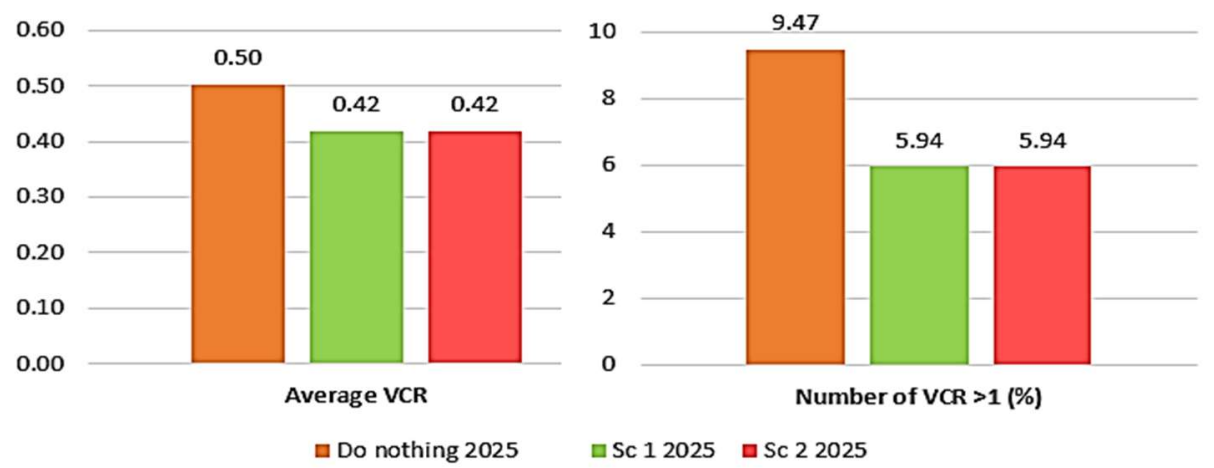

Figure 7. Comparisons between do-nothing scenario 2025, scenario 1 2025, and scenario 22025 in terms of average VCR (left) and number of links with VCR more than 1.0 (right) 
Further analysis of the average speed in the whole network is also conducted to evaluate the effectiveness of road infrastructures developments. The result from PTV Visum showed that the roads developments modelled in scenario 1 are effective to increase the average speed in the network. It is showed by the increase of average speed about $5 \mathrm{~km} / \mathrm{h}$ (see Figure 8).

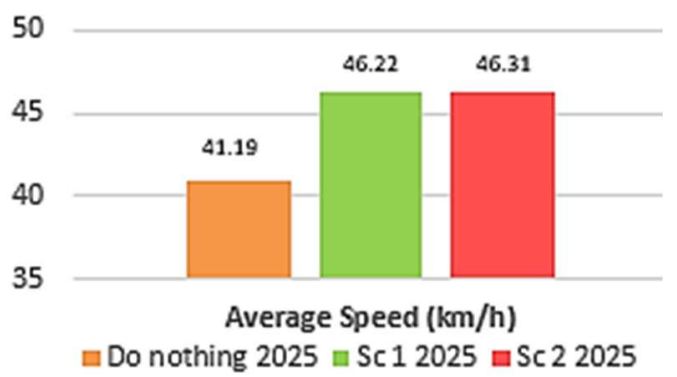

Figure 8. Change on average speed between do-nothing 2025, scenario 1 2025, and scenario 22025

While scenario 2 could only increase the average speed by $0.09 \mathrm{~km} / \mathrm{h}$. From the analysis conducted on the condition of the whole network, scenario 2 only has small impacts to improve the roads conditions in the study area. This is possible to happen because the scenario 2 only focused on managing the trips demand from and toward NYIA. Further analysis of the road access improvement to the airport will be presented later to show the specific impacts of scenario 2 .

\subsection{Analysis of Road Access to New Yogyakarta International Airport}

Further and more specific analysis of the impact of the new rail connection to the airport is conducted. This further analysis will focus on the impact of change in trips demand from the airport into the nearest railway stations.

According to the Department of Public Works (2017), the NYIA will be connected with two main access. The first route is located in the north and will pass Yogyakarta-Purworejo road, while the other one is located in the south and will connect to JJLS. Figure 9 below showed the difference in traffic volume in both road access after the airport train to the NYIA operated. From the figure below it can be seen that the volume in both main access to the airport is decreased, especially in the first route. The number of volume decreased in the first route can reach more than 200 pcu on peak hour, while in the second route the volume decreased between 0 and 200 pcu on peak hour. This decreased in volume in both main access to the airport showed that the operation of airport train is effective to reduce the road based trip to the airport.

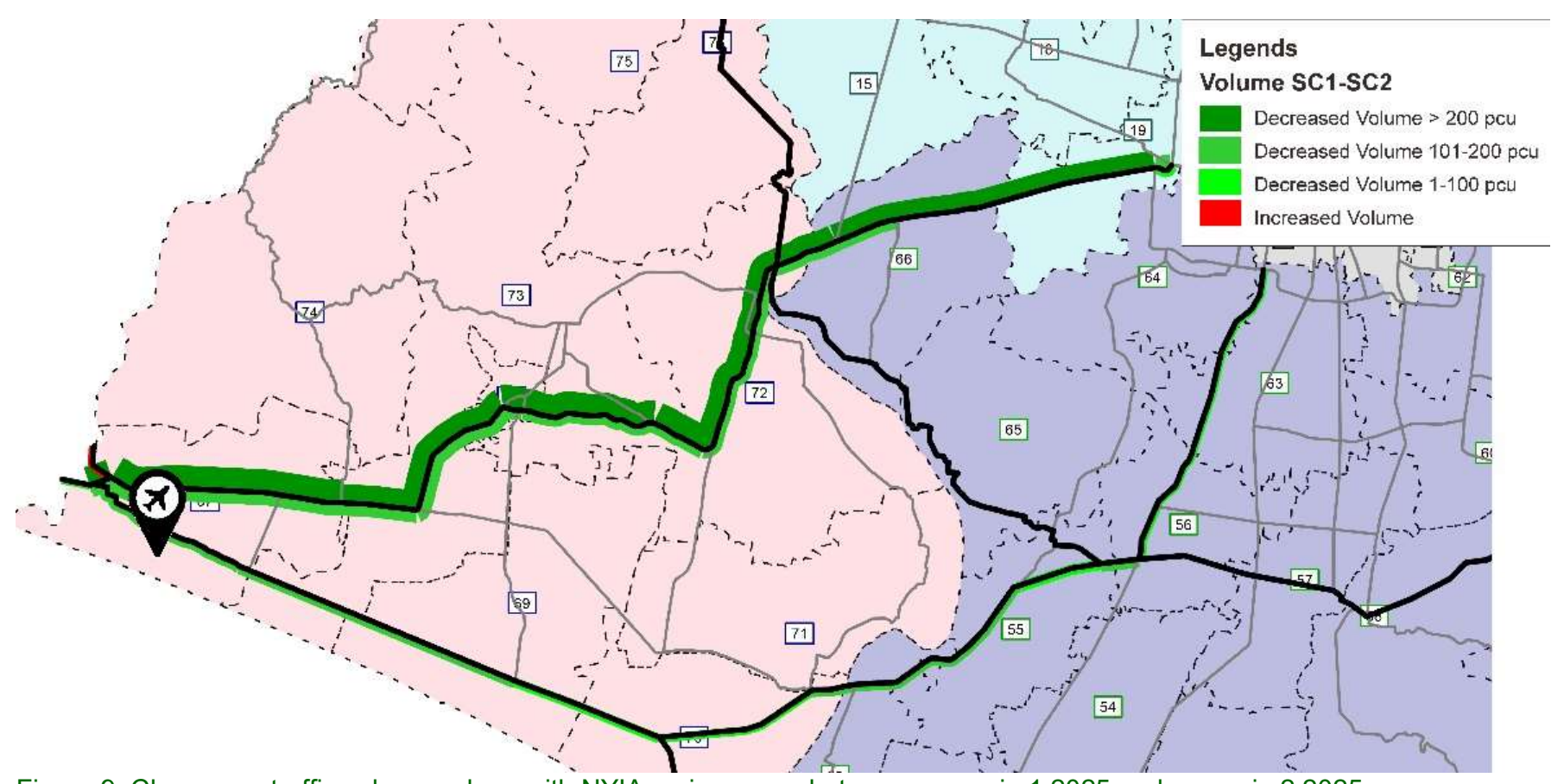

Figure 9. Change on traffic volumes along with NYIA main access between scenario 12025 and scenario 22025 
In term of average speed in both routes, Figure 10 below showed that the road improvement in one is also to increase the average speed in both routes, while the operation of rail service to the airport in scenario two will make a slight improvement on average speed if compared to scenario 1.

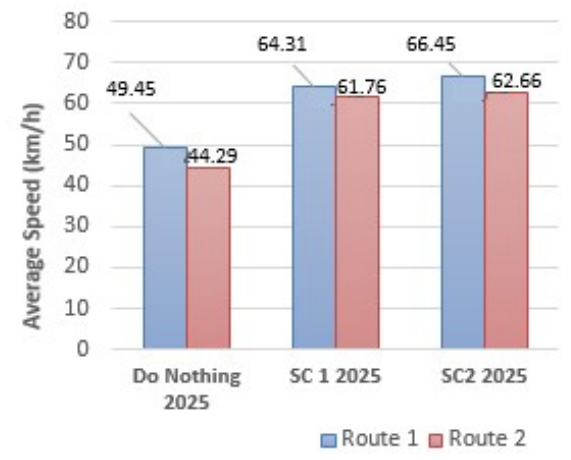

Figure 10. Average speed on the main access to NYIA

\subsection{Analysis on Impact of Airport Rail Service to Yogyakarta Urban Area}

The operation of rail service will change the origin and destination of the trip from the NYIA into the nearest railway station. This condition will change travel demand on Yogyakarta Railway Station in Gedongtengen district will be increased. Figure 11 below presented the volume difference in Yogyakarta Urban Area (YUA) between the implementation of scenario 1 and scenario 2. From figure 11, it can be seen that several links in the border area experienced a decrease in traffic volume. This could happen because the numbers of traffics going outside the city centre area are decreased. Meanwhile, the city centre area is showing some increase in traffic volume, especially near the train station area.

Figure 11 presents the volume difference in Yogyakarta Urban Area (YUA) between the implementation of scenario 1 and scenario 2 . From the figure, it can be seen that several links in the border area experienced a decrease in traffic volume. This could happen because the numbers of traffics going outside the city centre area are decreased. Meanwhile, the city centre area is showing some increase in traffic volume, especially near the train station area.

The graphs in Figure 12 showed that the operation of rail service to the airport only increases 0.01 on average VCR compared to the result in scenario 1 . Another analysis of the average speed differences between the two scenarios also showed that implementation of scenario two only has small impacts on the network. Figure 13 below showed that the implementation of scenario two only decreases the average speed by $0.09 \mathrm{~km} / \mathrm{h}$.

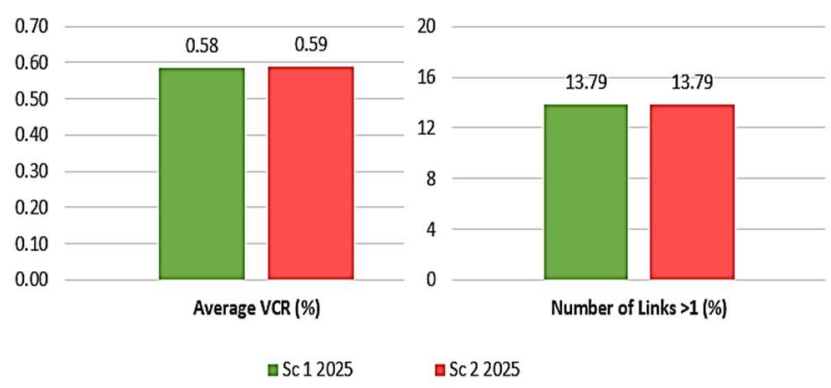

Figure 11. Comparisons between scenario 12025 and scenario 22025 in terms of average VCR (left) and number of links with VCR more than 1.0 (right) in YUA

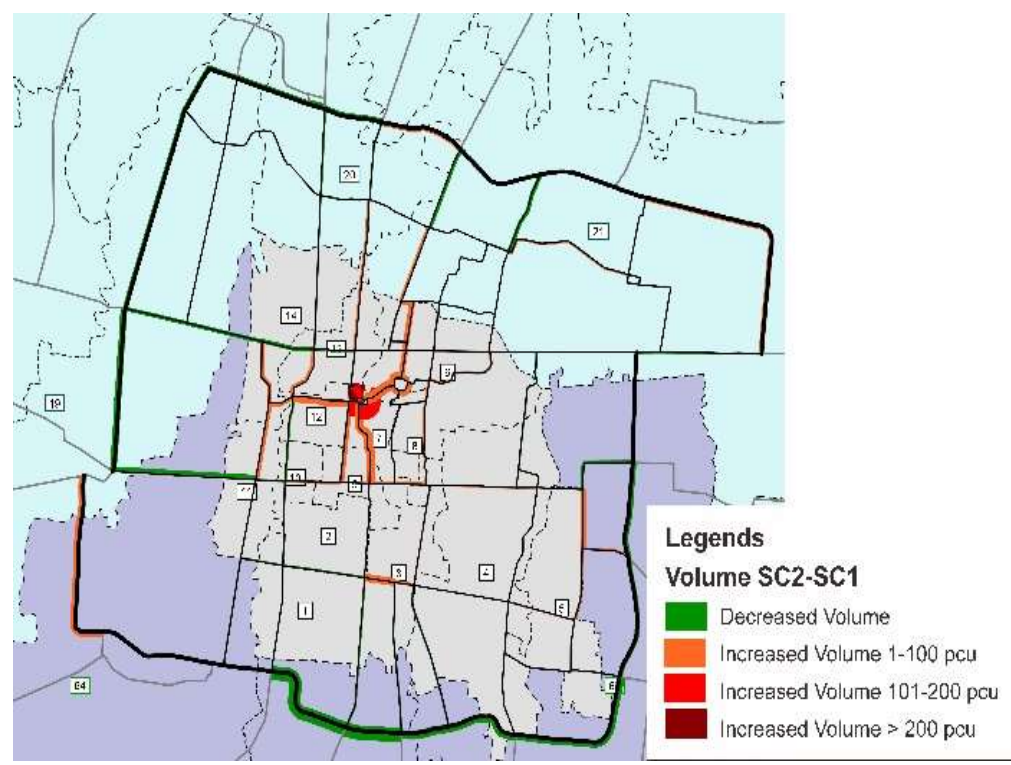

Figure 12. Change in traffic volumes in YUA between scenario 12025 and scenario 22025 


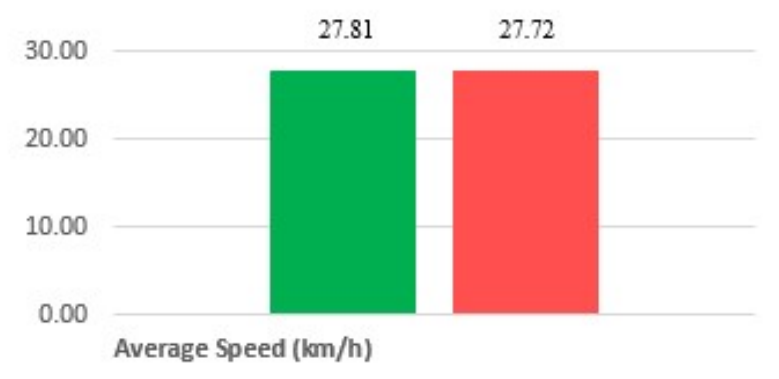

- $\mathrm{Sc} 12025 \quad$ Sc 22025

Figure 13. Average speed on YUA in scenario 12025 and scenario 22025

\section{CONCLUSIONS}

The change in land use can become the catalyst of urban development in an area. However, the development of a new area without supporting policies followed could be the source of the environmental and social consequences since the development would affect the increase in trips demand to the newly developed location.

The analysis of this study predicted the future generation and attraction of the new airport location, which is located in Temon district, an undeveloped area away from the city centre. The result stated that development of NYIA in Temon district would change trips demand on the location. In 2025, the number of trips generated and attracted to the location will reach six times higher than in 2015.

The increase of generation and attraction in Temon district will change the pattern of the trip in SRY generally and will affect the transport network performance in the study area. In do-nothing scenario 2025 , the number of congested links will increase significantly as well as the declining of the average speeds in the whole network. The situation in the SRY road network will be better with the implementations of roads improvement scenario. The result showed that total travel time in the whole network is lower compared to the do-nothing scenario, although the total travel distance will be increased due to the traffic diversion as the effect of the existence of some alternative routes. The result also showed that compared to do-nothing scenario, the number of congested links is decreased. The improvement also can be seen in the increase in average speeds in the overall network.
Lastly, The result showed that average speed in the airport road access will gradually increase along with the implementation of scenario 1 and scenario 2 . Another analysis showed that although the implementation of scenario 2 will increase the traffic in the city centre, this scenario did not show any valuable negative impact on VCR and average speed in the YUA.

\section{REFERENCES}

AASHTO (2011) A policy on geometric design of highways and streets.

Adi and Tamtomo, W. (2015) 'Valuing Manggarai Station-Soekarno-Hatta International Airport Rail Link Using Stated Preference Approach', in Journal of the Civil Engineering Forum (JCEF).

Angkasa Pura (2015) Air Traffic Growth in Adi Sutjipto International Airport. Yogyakarta.

Ashley, D. and Merz, S. K. (2006) 'Airport Rail Links-A Post Audit', in Australasian Transport Research Forum (ATRF), 29TH, 2006, Gold Coast, Queensland, Australia, Vol 29.

Department of Public Works (2017) Feasibility Study and Early Design on Jogja Outer Ring Road. Yogyakarta.

Directorate General Bina Marga (2017) Indonesian Road Pavement Manual. Jakarta.

Fitriatmaja and Irfan (2015) 'Perilaku Pemilihan Moda Transportasi Pengumpan Menuju Bandara Temon (Studi Kasus: Kereta Api dan Kendaraan Pribadi)' Universitas Gadjah Mada.

Indonesia Highway Agency (1997) Indonesian Highway Capacity Manual Jakarta.

Irawan, M. Z., Sumi, T. and Munawar, A. (2010) 'Implementation of the 1997 Indonesian highway capacity manual (MKJI) volume delay function', Journal of the Eastern Asia Society for Transportation Studies. Eastern Asia Society for Transportation Studies, 8, pp. 350-360.

Jou, R.-C., Hensher, D. A. and Hsu, T.-L. (2011) 'Airport ground access mode choice behavior after the introduction of a new mode: A case study of Taoyuan International Airport in Taiwan', Transportation Research Part E: Logistics and Transportation Review. Elsevier, 47(3), pp. 371-381.

Kereta Api Indonesia (2015) Proposal of Airport Train in Kulon Progo. 
Lindarto, D. (2017) 'The Determinant Factors of Regional Development Toward Land Use Change in Deli Serdang', in IOP Conference Series: Materials Science and Engineering. IOP Publishing, p. 12280.

Loo, B. P. Y. and Chow, A. S. Y. (2011) 'Spatial restructuring to facilitate shorter commuting: An example of the relocation of Hong Kong International Airport', Urban Studies. Sage Publications Sage UK: London, England, 48(8), pp. 1681-1694.

Ministry of Transport (2013) Determination of New Airport Location in Special Region of Yogyakarta.

Ortuzar, J. de D. and Willumsen, L. G. (2011) Modelling transport. John Wiley \& Sons.

Purwanto, B. et al. (2017) 'Strategic Decision In Airport Relocation: A Case Study From Kualanamu, Indonesia', Asian journal of management sciences \& education. Leena and Luna International, 6(3), pp. 69-76.

Rahayu, Y. E., Ahyudanari, E. and Pratomoadmojo, N. A. (2016) 'Land use development and its impact on airport access road', Procedia-Social and Behavioral Sciences. Elsevier, 227, pp. 31-37.
Smith, M. J. (1978) 'In a road network, increasing delay locally can reduce delay globally', Transportation Research. Elsevier, 12(6), pp. 419-422.

Suryadwanti, N. (2016) 'Penerapan Sistem In-Town Check-In Pada Stasiun Kereta Api Sebagai Fasilitas Pendukung Moda Akses Utama Menuju Bandara Baru Di Temon Kulon Progo', Jurnal Transportasi, 16(1).

Suwarsono and Hidayat, T. (2013) 'Analisis Pengembangan Jalur Kereta Menuju Rencana Bandara Baru Di Kulon Progo Yogyakarta'. Universitas Gadjah Mada.

UK Higways Agency (1996) Traffic Appraisal Advice, Design Manual for Roads and Bridges.

Yogyakarta Bureau of Statistics (2016) Population of Special, Population of Special Region of Yogyakarta. Available at: ttps://yogyakarta.bps.go.id/dynamictable/2017/08/32/ jumlah-penduduk-menurut-kabupaten-kota di d-iyogyakarta-jiwa (Accessed: 21 June 2018). 